\title{
A Weight of Seleucia in Pieria in Nea Paphos
}

\author{
ADAM ŁAJTAR
}

\begin{abstract}
Archaeological excavations carried out by a mission from the Jagiellonian University Institute of Archaeology on the site of the agora of Nea Paphos in Cyprus brought to light a lead weight with a Greek inscription giving the year 251 of an era and mentioning an agoranomos with the name Seleukos. On the basis of parallels, the author demonstrates that the weight must have been issued by the North Syrian city of Seleucia in Pieria, and the era used in the inscription is the civic era of Seleucia with the starting point in 109/108 BC, which allows one to date the object to AD 142/143. He argues that the structure where the object was found can tentatively be identified as agoranomeion of Nea Paphos.
\end{abstract}

Keywords: Cyprus, Nea Paphos, Seleucia in Pieria, ancient weights, agora

Adam Łajtar, Faculty of Archaeology, University of Warsaw, Warsaw; a.lajtar@uw.edu.pl; (D) 0000-0003-3842-2180

Since 2011, a mission from the Jagiellonian University Institute of Archaeology directed by Ewdoksia Papuci-Władyka has researched the agora of the ancient city of Nea Paphos in Cyprus. The research has an interdisciplinary character and is carried out with the use of both non-invasive methods and archaeological excavations. ${ }^{1}$ One of the excavated areas is the central part of the eastern portico of the agora, where a series of relatively small rooms dating from the late Hellenistic-early Roman period has come to light (Fig. 1). ${ }^{2}$ In one of the rooms, a lead weight (Fig. 2) was found in a stratum dating from the second century AD.

The weight is a plaque, $8.61 \mathrm{~cm}$ height, $8.89 \mathrm{~cm}$ wide, $0.73 \mathrm{~cm}$ thick, with a loop attached at the top. The plaque has a plain back-side, and on the front side, it carries a Greek inscription in six lines placed within a raised border. The object was executed in cast. Its weight is $451 \mathrm{~g}$.

\footnotetext{
${ }^{1}$ For the presentation of the results, see: Papuci-Władyka (Ed.) 2020.

${ }^{2}$ For a description of architectural remains unearthed in the area, see: Miszk 2020: 133, 140-143, 146-153, with Pls 24 and 41-46.
} 

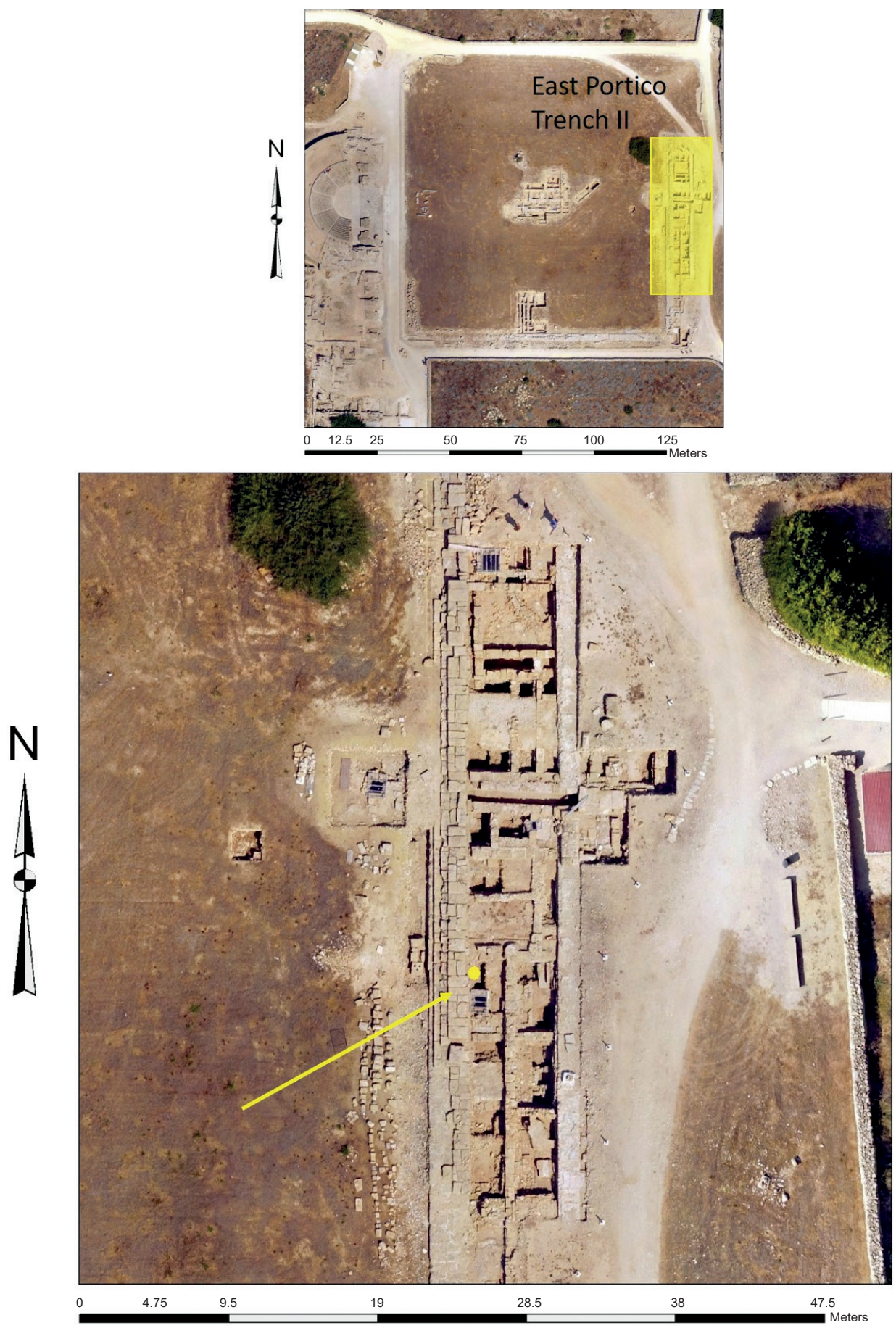

1. Ortophotomap of the agora excavations and the place of findspot of the Seleukos weight - East Portico Room 3 (Phot. and processing: W. Ostrowski, Ł. Miszk; courtesy of the Paphos Agora Project) 
2. Weight of Seleucia in Pieria found in Nea Paphos (Phot. M. Iwan; (C) Paphos Agora Project; courtesy of the Paphos Agora Project).

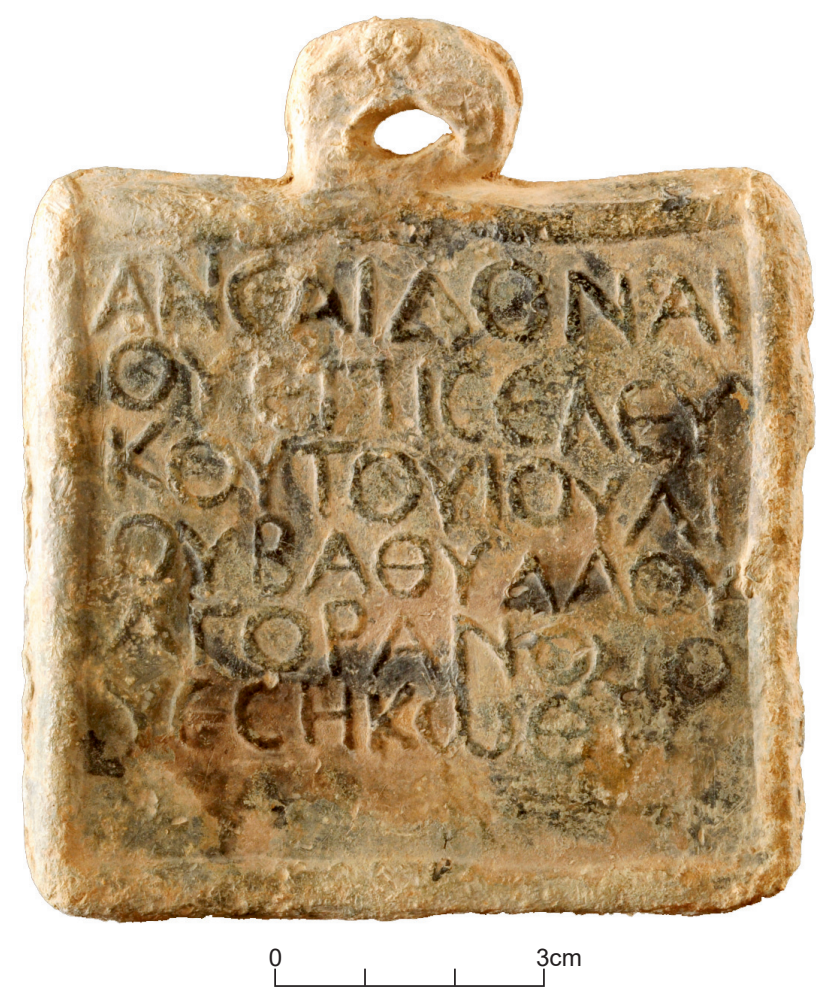

The object was published by Alfred Twardecki who read the inscription as follows: ${ }^{3}$

$$
\begin{aligned}
& \alpha v c^{\prime} \text { Aidoovaí- } \\
& \text { ov } \varepsilon^{\prime} \cdot\langle\dot{\varepsilon}\rangle \pi \grave{i} \Sigma \varepsilon \lambda \varepsilon v^{-}
\end{aligned}
$$

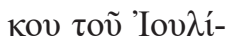

$$
\begin{aligned}
& 4 \text { ov Bató } \lambda \lambda \text { ov }
\end{aligned}
$$

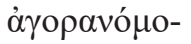

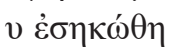

Twardecki translated:

'(In the year) 251 (month) Audnaios (day) 5, for Seleukos (son of) Ioulios Bathyllos, agoranomos, weighed'.

The correct translation should be:

'(Year) 251, 5 Aidonaios, (this weight) was weighed under the agoranomos Seleukos, son of Ioulios Bathyllos'.

\footnotetext{
${ }^{3}$ Twardecki 2020. Registered in Pondera database as no. 14503 based on Twardecki 2020.
} 
Aidonaios is a variant spelling of the month name commonly known as Audnaios. ${ }^{4}$ The spelling Aidonaios is attested mostly in Macedonia. Its presence in the inscription on the weight here discussed indicates that the city that issued the weight had Macedonian origins and maintained its Macedonian traditions long after its foundation.

Twardecki rightly observed that the use of the Macedonian calendar and the dating according to an era point at a non-Cypriot origin of the object. Considering that the weight can be dated to the second century AD on account of the archaeological context, he looked for an era with a starting point in the second century $\mathrm{BC}$, such as the era of the province of Macedonia or the eras of the cities of the province of Asia, but finally concluded that the question of dating (and consequently provenance) the object could not be solved under the current state of research.

In fact, the weight comes from the North Syrian city of Seleucia in Pieria and is dated according to a civic era with a starting point in 109/108 BC, the year it obtained its civic autonomy. ${ }^{5}$ It belongs to the third series of civic weights of Seleucia in Pieria according to the classification of Henri Seyrig. ${ }^{6}$ The weights of the series are characterised by a common form (a square plaque with a handle or a loop at the top, sometimes also at the bottom) and an inscription containing the date according to the civic era, day of month according to the Macedonian calendar, the name of the current agoranomos occasionally provided with information that he oversaw weighing the weight, and an indication of the mass. ${ }^{7}$ The list of these weights including objects both known to Seyrig and published in more recent times is as follows (in chronological order, with undated objects placed at the end):

(1) Found in Antakya (Antiochia ad Orontem) in 1904; now in the Archaeological Museum Istanbul, inv. no. $2399(\mathrm{M})$; lead; cast; plaque $7.7 \times 7.8 \mathrm{~cm}$; handle at the top; mass:

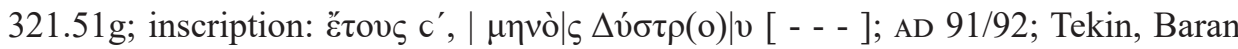
Çeklik 2013: no. 74, Pl. 20; Pondera no. 1765;

(2) The object discussed in this paper; found in Nea Paphos by the Jagiellonian University archaeological mission; lead; cast; plaque $8.6 \times 8.9 \mathrm{~cm}$; loop at the top; mass: $451 \mathrm{~g}$;

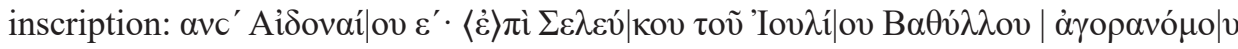
$\dot{\varepsilon} \sigma \eta \kappa \omega ́ \theta \eta ;$ AD 142/143; Twardecki 2020; Pondera no. 14503;

(3) Excavated in Seleucia by the Princeton and Louvre archaeological mission; present whereabouts unknown; lead; cast; plaque $8 \times 8 \mathrm{~cm}$; loop at the top, handle at the

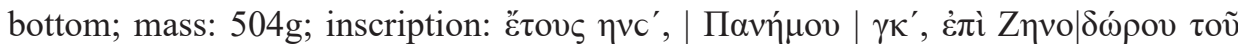

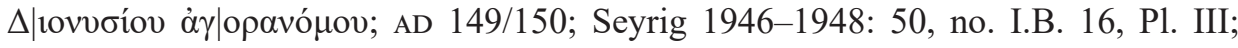
IGLS III 1213j; Pondera no. 3611;

(4) Findspot unknown; purchased in Istanbul for the Berlin Antiquities Collections in 1927, inv. no. 31492; lost; known from a drawing in the inventory book; lead; cast;

\footnotetext{
${ }^{4}$ For the spelling of the month's name and its etymology, see: Alonso Déniz 2020.

${ }^{5}$ On the margin of the present discussion, one should observe that the letter of Antiochos VIII Grypos to Ptolemy X Alexander announcing the grant of autonomy to Seleucia was published in a monumental form in the temple of Aphrodite in Palaepaphos (Cayla 2018: no. 22).

${ }^{6}$ Seyrig 1946-1948: 45-52. The article was reedited in: Seyrig 1985: 367-415 (not consulted by me).

${ }^{7}$ The form of the inscription may vary from object to object, with some of its elements being omitted.
} 
plaque $7.6 \times 8 \mathrm{~cm}$; handle at the top; mass: unknown; inscription: $\alpha \mathrm{oc}^{\prime}, \Delta \varepsilon \varepsilon^{\prime} \mathrm{ov} \mid \gamma \kappa^{\prime}$, غ̇лì

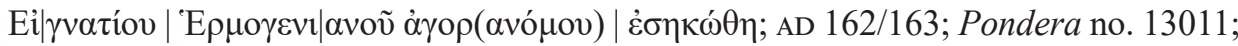

(5) Findspot unknown (but see below); now in the National Museum in Beirut; lead; cast; plaque $7 \times 7 \mathrm{~cm}$; handle at the top; mass: $294 \mathrm{~g}$ (according to Seyrig), $220.5 \mathrm{~g}$ (according to Pierre-Louis Gatier); inscription: ह̌兀

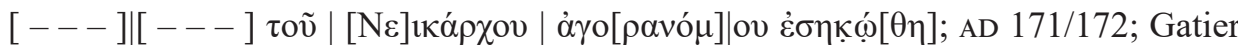
in: Yon, Aliquot 2016: no. 535; Pondera no. 3608; the object was already known to Seyrig and its description is found in Seyrig's papers (Bibliothèque nationale de France, HS 328); Seyrig indicated that the object was acquired in the antiquities market in Istanbul with the provenance Adalia (Antalya); he read the inscription as

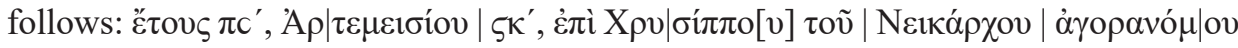
$\dot{\varepsilon} \sigma \eta \kappa \omega ́<\theta>\eta ;$

(6) Presumably acquired in Lataqia (Laodicaea); now in the Archaeological Museum of the American University of Beirut, inv. no. 4767 ; lead; cast; plaque $8.3 \times 8.3 \mathrm{~cm}$; loop

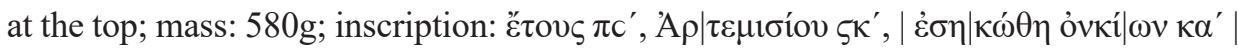
$\lambda i \tau \rho(\alpha)$; AD 171/172; Seyrig 1946-1948: 51, no. I.B. 17; IGLS III 1213k; Pondera no. 3605 ;

(7) Acquired in Magharadjik, archaeological site of Seleucia in Pieria; once in the National Museum in Beirut; lead; cast; plaque $5.7 \times 6.3 \mathrm{~cm}$; loop at the top; mass: $227 \mathrm{~g}$;

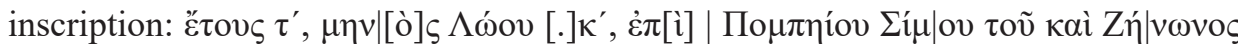

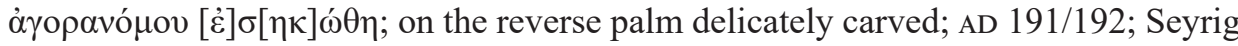
1946-1948: 51, no. I.B. 18; IGLS III 12131; Pondera no. 3607;

(8) Found near Antioch; acquired in Aleppo by William Henry Waddington; now in Bibliothèque Nationale de France, inv. no. Bronze 2249 (ex reg. F. 1826); lead; cast; plaque $7.8 \times 9.1 \mathrm{~cm}$; loop at the top; mass: $340 \mathrm{~g}$; inscription: हैं $\tau 00 \varsigma \gamma\left(\tau^{\prime}, \mu \eta \mid\right.$ vò $\varsigma$

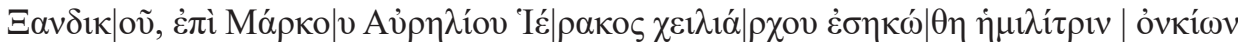
$1<$; AD 204/205; Le Bas, Waddington 1870: no. 2713; Babelon, Blanchet 1895: no. 2249; Seyrig 1946-1948: 51, no. I.B. 19; IGLS III 1213m; Pondera no. 3606;

(9) Findspot unknown; now in the Art and History Museum in Geneva, inv. no. CdN 2017-002; lead; cast; plaque $6 \times 6.5 \mathrm{~cm}$; loop at the top; mass: $161.4 \mathrm{~g}$; inscription:

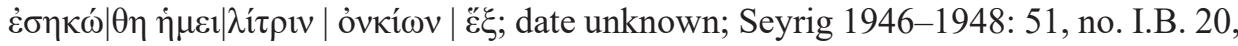
Pl. IV; IGLS III 1213n; Pondera no. 3609;

(10) Findspot unknown; in the antiquities trade; lead; cast; plaque $6.4 \times 7.8 \mathrm{~cm}$; loop at the

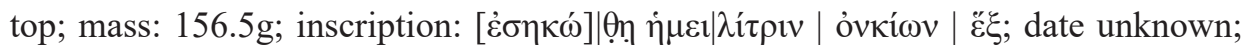
Auction Münz-Zentrum 1979: 39, no. 4079; Pondera no. 3610;

(11) Found in Antakya (Antiochia ad Orontem) in 1904; now in the Archaeological Museum Istanbul, inv. no. $2398(\mathrm{M})$; lead; cast; plaque $7.8 \times 8.4 \mathrm{~cm}$; handle at the top; mass:

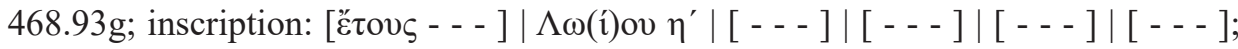
date unknown; Tekin, Baran Çeklik 2013: no. 72, Pl. 19; Pondera no. 1763.

It can easily be observed that none of the weights listed above contains explicit information about the issuing city, but the discovery of two objects on the site of Seleucia in Pieria 
makes attribution of the entire series to this city nearly certain. Furthermore, Pompeius Simos, also called Zenon, attested as agoranamos in (7), might have been a descendant of Cneius Pompeius Zenon known through an inscription from Seleucia in Pieria dated to $\mathrm{AD} 121 / 122$, as observed by Seyrig. ${ }^{8}$ The earliest weight of the list (1) is dated to the year 200 of the civic era of Seleucia in Pieria (AD 91/92) and the latest (8) to the year 313 (AD 204/205). The weight from Nea Paphos (2) dated to the year 251 (AD 142/143) is the second earliest of known example of the weights of the third series.

Twardecki supposed that the weight from Nea Paphos with its $451 \mathrm{~g}$ corresponds to one mina. It is known that Hellenistic weights of Seleucia in Pieria (series 1 and 2) were based on the mina, which weighed between $500 \mathrm{~g}$ and $600 \mathrm{~g}$ as suggested by Seyrig. ${ }^{9}$ As far as the weights of the third series are concerned, there are three stated or deduced systems: (1) the Roman libra of $c .327 \mathrm{~g}$ divided into 12 ounces of $c .27 \mathrm{~g}$ (nos. [1], [6] and [9] above); (2) a double litra of c. $340 \mathrm{~g}$, i.e. $680 \mathrm{~g}$, based on an ounce calculated as weighing c. 32.4g (no. [8] above); (3) a mina of c. 450+g (nos. [5] and [7], and perhaps also [3] above). The Nea Paphos specimen obviously represents the third system, which may be the continuation of the mina of the series 1 and 2 .

The main point of interest connected with the weight discussed in this paper is related to the place of its discovery. Ancient Greek cities, even those which were immediate neighbours and shared a common history, as for example Seleucia in Pieria and Antioch, had different metrological systems, which made the use of weights of one city in the territory of the other at least inconvenient if not impossible. Besides, cities followed the rule that any commercial activity carried out in their territories was made with the use of official civic instruments. Provisions to this effect are clearly expressed in civic decrees regulating the functioning of the market preserved in the form of inscriptions. One can mention here the Athenian decree about the functioning of the agora from the end of the second century $\mathrm{BC},{ }^{10}$ the Delian decree about the sale of wood products from the mid-third century $\mathrm{BC}^{11}$ and the passage about commerce in the inscription about the organisation of mysteries in Andania in the Peloponnesus dating from 92 BC. ${ }^{12}$ Non-compliance with this rule resulted in confiscation of the incriminated instruments, and, in notorious cases, confiscation of traded goods, fines, and corporal punishments when the delinquent was a slave. ${ }^{13}$ Because of all this, weights travelled very rarely between cities in antiquity. ${ }^{14}$ If they are found outside their cities of origin, they as a rule got there in modern times,

${ }^{8}$ Seyrig 1946-1948: 52. The inscription in question is IGLS III 1185.

9 Seyrig 1946-1948: 76. Actually the lightest weight of the series 1 and 2 known to him weighed c. $456 \mathrm{~g}$ and the heaviest c. 571g.

${ }^{10} I G$ II-III ${ }^{2}$ 1013. New edition: Doyen 2016. The provision that interests us here is contained in lines $7-11$ of the inscription.

${ }^{11} I D$ 509. On this inscription, see most recently: Chankowski 2012.

${ }^{12}$ IG V 1, 1390, 11. 100-103.

${ }_{13}$ See remarks by Killen 2019: 20-21.

${ }_{14}$ As rare examples one can mention two Tyrian weights found in Gezer and Ashdod-Yam (Wolff, Finkielsztejn 2009) and six weights of a South Leventine city (or cities) found in a shipwreck near 'Atlit (Galili et al. 2016: 8-14). 
in connection with commerce in antiquities. ${ }^{15}$ The situation with the weight studied in this paper is different, however. It was found during regular excavations, in an undisturbed archaeological layer, well dated to the second century AD, which means that it was exported from its city of origin shortly after its creation in AD 142/143. Who took it away and for what reason is impossible to say. One thing is certain, however: the weight could not have been used as a weight measure in commercial transactions in the agora of Nea Paphos. Its presence in one of the rooms in the eastern portico of the agora can be explained only through the assumption that it was confiscated by the agoranomos and kept in his office, which allows one to hypothesise that the room where the weight was found played the role of agoranomeion or a part of it. However attractive, this hypothesis needs further evidence, either inscriptional or artefactual, to be proven positively.

Whatever the reasons for the exportation of a weight of Seleucia in Pieria to Nea Paphos, the weight provides tangible evidence of contacts between these two cities. The existence of such contacts is fully understandable considering the close proximity of Cyprus and Northern Syria, and the location of Nea Paphos on the sea route that connected Seleucia in Pieria, the port of Antioch, with the Aegean basin and the areas further to the west. Such contacts are well visible in the archaeological material. John Lund observed that, starting with the second century BC, great amounts of Northern Syrian pottery, especially Eastern Sigillata A ware, reached South-west Cyprus. ${ }^{16}$ Eastern Sigillata A is well represented in the material from the Nea Paphos agora excavations. ${ }^{17}$ It continued to be imported in what the excavators call Period 3, which overlaps with the date of the lead weight, though the peak of such imports was probably earlier than that. In this context, let us remember that the first journey of Saint Paul, during which he traversed Cyprus from Salamis to Nea Paphos, started exactly in Seleucia (Act. 13.4-12).

\section{Acknowledgements}

I thank Andrzej Chankowski, Simone Killen, and John Lund for help in reaching the scholarly literature. I also thank Giovanni Ruffini for improving the English of the paper, two anonymous reviewers for enriching the final version with their remarks, and Ewdoksia Papuci-Władyka for providing the photos of the object and the excavation area.

\section{References}

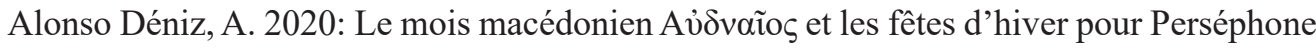

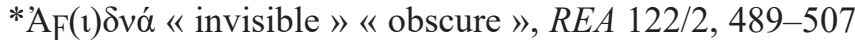

Auction Münz-Zentrum 1979: Münz-Zentrum Albrecht + Hoffmann GmBH, Auction 37: Gewichte aus drei Jahrtausenden II (Cologne, 08/11/1979), Köln

${ }^{15}$ See remarks in: Gatier 2014: 41-42. Two Syrian weights (one of Antioch, the other one of Laodicaea) are kept in the Pierides Collection in Larnaca; cf. Gatier 1986. They were acquired in the antiquities market and their archaeological provenance is unknown.

16 Lund 2013.

${ }^{17}$ Kajzer, Marzec 2020: 262, Table 1, showing the chronological distribution of finds. 
Babelon, E., Blanchet, J.-A. 1895: Catalogue des bronzes antiques de la Bibliothèque nationale, Paris

Cayla, J.-B. 2018: Les inscriptions de Paphos. La cité chypriote sous la domination lagide et à l'époque imperiale, TMO 74, Lyon

Chankowski, V. 2012: Délos et les matériaux stratégiques. Une nouvelle lecture de la loi délienne sur la vente du bois et du charbon (ID 509), [in:] Konuk, K. (Ed.), Stephanèphoros. De l'économie antique à l'Asie Mineure. Hommages à Raymond Descat, Ausonius Éditions, Mémoires 28, Bordeaux, 31-51

Doyen, Ch. 2016: Ex schedis Fourmonti. Le décret agoranomique athénien (CIG I 123 $=\mathrm{IG}$ II-III' 1013), Chiron 46, 453-487

Galili, E., Syon, D., Finkielsztejn, G., Sussman, V., Stiebel, G.D. 2016: Late Ptolemaic Assemblages of Metal Artifacts and Bronze Coins Recovered off the Coast of 'Atlit, 'Atiqot 87, 1-35

Gatier, P.-L. 1986: Deux poids syriens de la Fondation Piéridès, Syria 63/3-4, 375-378

Gatier, P.-L. 2014: Poids et vie civique du Proche-Orient hellénistique et romain, [in:] Saliou, C. (Ed.), La mesure et ses usages dans l'Antiquité : la documentation archéologique. Journée d'étude de la Société française d'archéologie classique, 17 mars 2012, DHA Supplément 12, Besançon, 125-162

Kajzer, M., Marzec, E. 2020: Roman Table Ware Pottery (ca. 30 BCE to the $7^{\text {th }}$ century CE), [in:] Papuci-Władyka, E. (Ed.), Interdisciplinary Research of the Jagiellonian University in Nea Paphos UNESCO World Heritage Site (2011-2015) - First Results, Paphos Agora Project 1, Cracow, 249-277

Killen, S. 2019: Antiker Verbraucherschutz. Wie griechische Stadtstaaten durch offizielle Maße und Gewichte für fairen Handel sorgten, AntWelt 50/1, 17-21

Le Bas, Ph., Waddington, H.W. 1870: Voyage archéologique en Grèce et Asie Mineure III. Inscriptions grecques et latines recueillies en Grèce et en Asie Mineure, Paris

Lund, J. 2013: Eastern Cyprus and the Northern Levantine Coast in the Hellenistic Period: The Ceramic Connection, [in:] Fenn, N., Römer-Strehl, Ch. (Eds), Networks in the Hellenistic World According to the Pottery in the Eastern Mediterranean and beyond, BAR-IS 2539, Oxford, 221-225

Miszk, Ł. 2020: Stratigraphy and Architecture of the Agora, [in:] Papuci-Władyka, E. (Ed.), Interdisciplinary Research of the Jagiellonian University in Nea Paphos UNESCO World Heritage Site (2011-2015) - First Results, Paphos Agora Project 1, Cracow, 127-184

Papuci-Władyka, E. (Ed.) 2020: Interdisciplinary Research of the Jagiellonian University in Nea Paphos UNESCO World Heritage Site (2011-2015) - First Results, Paphos Agora Project 1, Cracow

Pondera: Pondera online. An Online Database of Ancient and Byzantine Weights, https://pondera.uclouvain.be (accessed August, 2021)

Seyrig, H. 1946-1948: Poids antiques de la Syrie et de la Phénicie sous la domination grecque et romaine, BMBeyr 8, 37-79

Seyrig, H. 1985: Scripta Varia. Mélanges d'archéologie et d'histoire, $B A H$ 125, Paris 
Tekin, O., Baran Çeklik, G. 2013: Istanbul Archaeological Museums: Greek, Roman, Byzantine and Islamic Weights in the Department of Metal Objects, Corpus Ponderum Antiquorum et Islamicorum, Turkey 2, Istanbul

Twardecki, A. 2020: Lead Weight with an Inscription by Seleukos, [in:] Papuci-Władyka, E. (Ed.), Interdisciplinary Research of the Jagiellonian University in Nea Paphos UNESCO World Heritage Site (2011-2015) - First Results, Paphos Agora Project 1, Cracow, 419-420

Wolff, S.R., Finkielsztejn, G. 2009: Two New Hellenistic Lead Weights of the Tanit Series, [in:] Schloen, J.D. (Ed.), Exploring the Longue Durée: Essays in Honor of Lawrence E. Stager, Winona Lake, Ind., 497-506

Yon, J.-B., Aliquot, J. 2016: Inscriptions grecques et latines du Musée national de Beyrouth, BAAL Hors-Série 12, Beirut 


\section{ÉTUDES et TRAVAUX XXXIV / 2021}
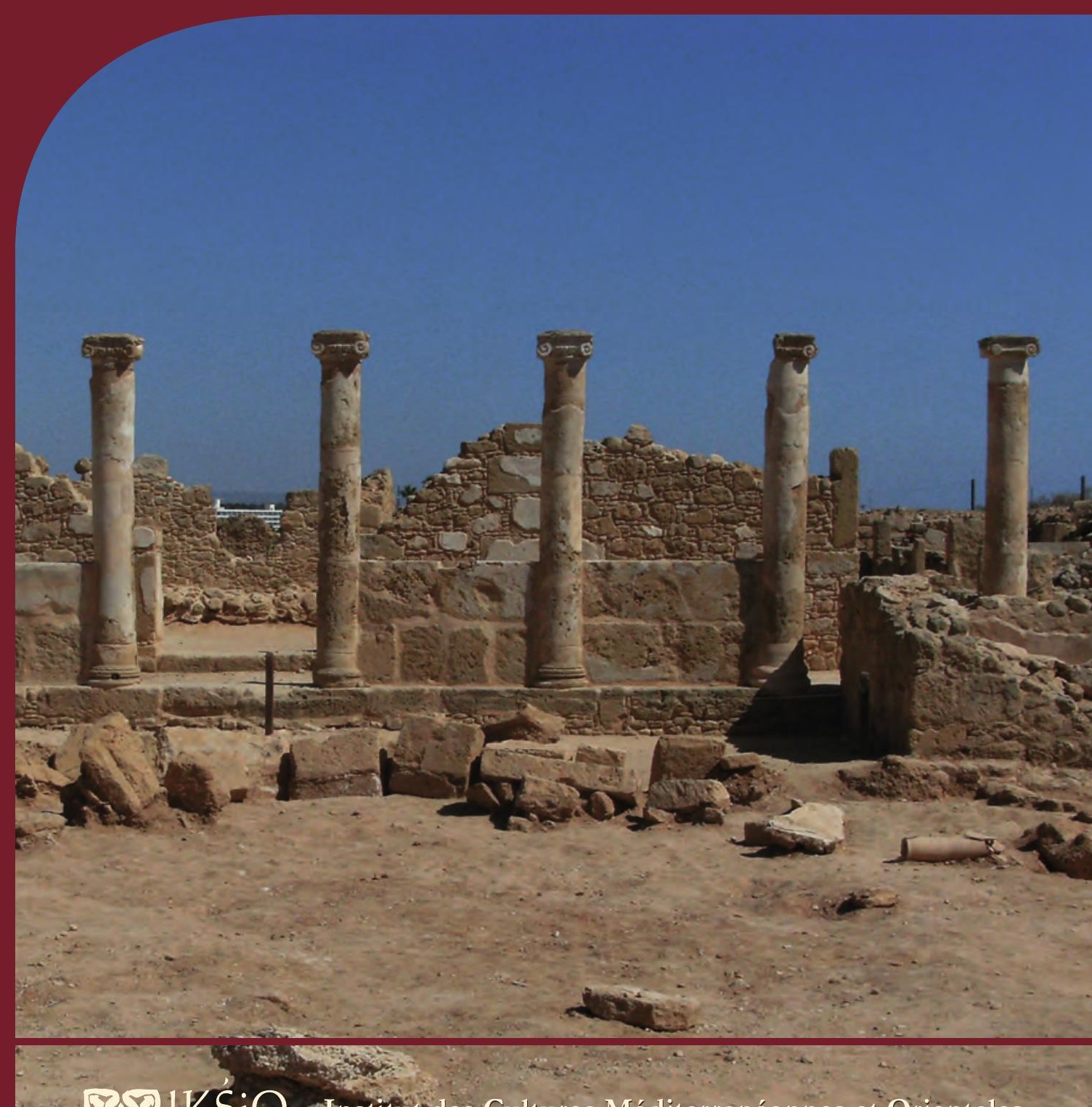

W $92 \mathrm{HKSiO}$ Institut des Cultures Méditerranéennes et Orientales

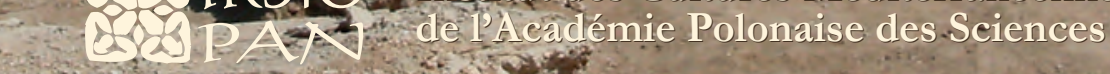

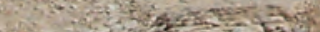

Q 
COMITÉ DE RÉDACTION SCIENTIFIQUE

Maciej Makowski - rédacteur en chef

Jadwiga Iwaszczuk - rédacteur

Katarzyna Kapiec - secrétaire de la rédaction

Henryk Meyza - rédacteur thématique du volume

CONSEIL SCIENTIFIQUE DU JOURNAL

M. Kobusiewicz (IAE PAN, Warszawa)

E. Laskowska-Kusztal (IMOC PAS, Warszawa)

D. Michaelides (University of Cyprus, Nicosia)

J.Ch. Moretti (IRAA-MOM, Université de Lyon 2/CNRS)

D. Raue (Ägyptisches Museum der Universität Leipzig)

P. Reynolds (ICREA, España)

D. Welsby (British Museum, London)

COMITÉ SCIENTIFIQUE DE LECTURE

la liste des membres du comité est accessible en ligne sur

http://www.etudesettravaux.iksiopan.pl

RÉDACTION TECHNIQUE

Marta Kaczanowicz

REVUE DES TEXTES EN ANGLAIS

Jo Harper 
ÉTUDES et TRAVAUX XXXIV 
INSTYTUT KULTUR ŚRÓDZIEMNOMORSKICH I ORIENTALNYCH POLSKIEJ AKADEMII NAUK

\title{
STUDIA i PRACE
}

\section{XXXIV}

\author{
GoIKSiO \\ QSO PAN \\ WARSZAWA \\ 2021
}


INSTITUT DES CULTURES MÉDITERRANÉENNES ET ORIENTALES DE L’ACADÉMIE POLONAISE DES SCIENCES

\section{ÉTUDES et TRAVAUX}

XXXIV

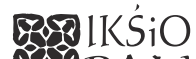

EOSPAN

VARSOVIE

2021 
Publication scientifique financée dans le cadre du programme du Ministre de la Science et de l’Éducation Supérieure

« Programme National de Développement de l’Humanistique » pour les années 2016-2021 (projet no 3bH 150099 83)

\title{
(1) NARODOWY PROGRAM ROZWOJU HUMANISTYKI
}

\author{
Copyright $(C)$ \\ Instytut Kultur Śródziemnomorskich i Orientalnych PAN \\ et les Auteurs \\ Warszawa 2021
}

ISSN 2084-6762

(jusqu'en 2011 : 0079-3566)

e-ISSN 2449-9579
Version première en papier, imprimée en Pologne - 150 copies
Version électronique accessible sur
http://www.etudesettravaux.iksiopan.pl

Édition: Polskie Towarzystwo Historyczne et Wydawnictwo Neriton, Warszawa

Conception générale de la couverture : J. Iwaszczuk

Photographie de couverture : Phot. A. Brzozowska-Jawornicka

(Le portique ionique est, péristyle de la Maison « hellénistique », Nea Paphos) 


\section{Table des matières}

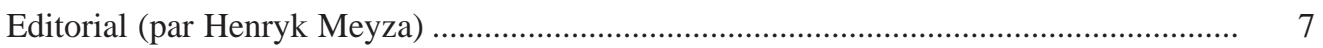

Marta BaJTLER

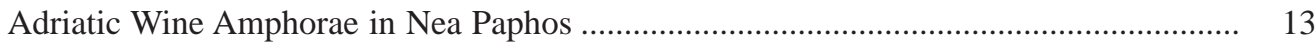

Claire Balandier, Jolanta MlynarczyK

The Temple and Its Surroundings on Fabrika Hill, Paphos: Preliminary Results

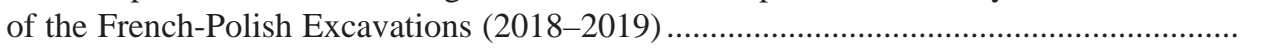

Grażyna BĄKowska-Czerner, Rafal CzERner

The Shell Motif in the Culture and Architecture of the Ancient Town of Marina el-Alamein in Egyp

AleKsandra BrzozowsKa-JaWornicKa

'Hellenistic' House in Nea Paphos, Cyprus - A First Summary of Its Architecture.

AleKsandra BrzozowsKa-JaWORnicKA, AnNa KuBICKA-SowińsKa

In Search of the Module in the Architectural Design of the 'Hellenistic'

House in Nea Paphos, Cyprus

RoKsana HaJduga

Kushite Stamp Impressions from Selib 2, Sudan

ERSIN HusSEIN

Mapping Metal Rich Roman Cyprus: The Case for Object-Centred Approaches

BARBARA LICHOCKA

Villa of Theseus at Nea Paphos (Cyprus). Fourth-Early Fifth Century Numismatic

Evidence for Architectural Transformations and Seismic Events

VASiliki Lysandrou, Demetrios Michaelides

Wall Paintings in Ancient Cyprus: The Hellenistic and Roman Tombs of Paphos

and Its Region

ADAM ŁAJTAR

A Weight of Seleucia in Pieria in Nea Paphos

Diana MroczeK

Ancient Portrait Busts of Marcus Aurelius in the National Museum in Poznań 
Brandon R. Olson, R. Scott Moore, Thomas Landvatter, Justin Stephens

Pyla-Vigla: A Case Study Assessing the Imperial Strategies of the Hellenistic

Diadochoi in Cyprus

Patrizio Pensabene, Eleonora Gasparini

Colonnaded Hall in Kourion: How the Oecus Corinthius Was Interpreted in the Roman

Houses of Cyprus

Monika Rekowska, Demetrios Michaelides, Skevi Christodoulou, JAKUB KANISZEWSKI

Adopting Roman Habits - The Baths in the House of Orpheus in Nea Paphos

as a 'Troublesome' Case Study?

MARCIN M. ROMANIUK

Terracotta Pipelines at Maloutena: Remarks on the Water System in the

Residential District of Ancient Nea Paphos, Cyprus

363

ABRÉVIATIONS

407 